\title{
The Athinson Family
}

I M P I N T I H I GHER E D U C A T O N

The Atkinson Family Foundation has endowed this imprint to

illuminate the role of higher education in contemporary society. 
The publisher gratefully acknowledges the generous support of the Higher Education Endowment Fund of the University of California Press Foundation, which was established by a major gift from the Atkinson Family Foundation. 
Dynamics of the Contemporary University 
THE CLARK KERR LECTURES ON THE ROLE OF HIGHER EDUCATION IN SOCIETY

A Larger Sense of Purpose: Higher Education and Society, by Harold T. Shapiro (Princeton University Press)

The American Research University from World War II to World Wide Web: Governments, the Private Sector, and the Emerging Meta-University, by Charles M. Vest

Searching for Utopia: Universities and Their Histories, by Hanna Holborn Gray Dynamics of the Contemporary University: Growth, Accretion, and Conflict, by Neil J. Smelser 


\section{Dynamics of the Contemporary University}

G R OWTH, A C C R E T I O N,

A N D C O N F L I C T

N E I L J . S M E L S E R

\section{뚜}

UNIVERSITY OF CALIFORNA PRESS

Berkeley Los Angeles London

CENTER FOR STUDIES IN HIGHER EDUCATION Berkeley 
The Center for Studies in Higher Education at the University of California, Berkeley, is a multidisciplinary research and policy center on higher education oriented to California, the nation, and comparative international issues. CSHE promotes discussion among university leaders, government officials, and academics; assists policy making by providing a neutral forum for airing contentious issues; and keeps the higher education world informed of new initiatives and proposals. The Center's research aims to inform current debate about higher education policy and practice.

University of California Press, one of the most distinguished university presses in the United States, enriches lives around the world by advancing scholarship in the humanities, social sciences, and natural sciences. Its activities are supported by the UC Press Foundation and by philanthropic contributions from individuals and institutions. For more information, visit www.ucpress.edu.

University of California Press

Berkeley and Los Angeles, California

University of California Press, Ltd.

London, England

(C) 2013 by The Regents of the University of California

Library of Congress Cataloging-in-Publication Data

Smelser, Neil J.

Dynamics of the contemporary university : growth, accretion, and conflict / Neil J. Smelser.

pages $\mathrm{cm}$

ISBN 978-0-520-27581-2 (hardback)

1. Universities and colleges-United States. 2. Universities and colleges-Administration-United States. 3. Educational changeUnited States. I. Title.

$$
\begin{array}{ll}
\text { LA227.4.S581 } & 2013 \\
378.73-\mathrm{dc} 23 &
\end{array}
$$

2012039812

Manufactured in the United States of America

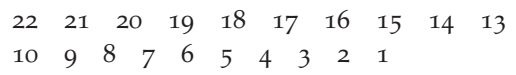

In keeping with a commitment to support environmentally responsible and sustainable printing practices, UC Press has printed this book on Rolland Enviro 100, a 100\% post-consumer fiber paper that is FSC certified, deinked, processed chlorine-free, and manufactured with renewable biogas energy. It is acid-free and EcoLogo certified. 